\title{
Cybercrime dan Cybersecurity pada Fintech: Sebuah Tinjauan Pustaka Sistematis
}

\section{Cybercrime and Cybersecurity at Fintech: A Systematic Literature Review}

\author{
Alexander Anggono \\ Program Studi Magister Akuntansi, Universitas Trunojoyo Madura \\ email: alexander.anggono@trunojoyo.ac.id \\ Tarjo \\ Program Studi Magister Akuntansi, Universitas Trunojoyo Madura \\ email: tarjo@trunojoyo.ac.id \\ Moh. Riskiyadi* \\ Program Studi Magister Akuntansi, Universitas Trunojoyo Madura \\ email: mohriskiyadi@gmail.com
}

\begin{abstract}
This study is intended to determine the cybercrime challenges faced by the fintech industry as well as anticipatory actions in the form of cybersecurity to overcome these challenges. This study employs a systematic literature review method from various articles discussing cybercrime and cybersecurity in fintech that were published in reputable online databases. The findings indicate that cybercrime problems in fintech consist of cybercrime regulations that are not strict, data and information theft, and intellectual property theft in which impacting on the reputation of fintech. Cybersecurity as an attempt to tackle cybercrime in fintech can be performed through proactive action, strengthening regulations, and establishing a reliable cybersecurity framework or procedure. The implications of this research are as an additional reference for academics, practitioners, regulators, and fintech actors related to the fast pace development of cybercrime and cybersecurity in fintech. The limitation of this study is that it only provides an overview and elaborate the results of prior studies instead of provide a further analysis of the relationship between the articles discussed. Recommendations for further research are to increase the scope of the articles studied or apply other literature review methods or conduct empirical research to confirm the results of this study.
\end{abstract}

Keywords: Cybercrime, cybersecurity, financial technology, fintech regulation, intellectual property theft.

\begin{abstract}
ABSTRAK
Penelitian ini bertujuan untuk mengetahui tantangan cybercrime yang dihadapi industri fintech serta tindakan antisipasi berupa cybersecurity untuk menanggulangi tantangan tersebut. Penelitian ini menggunakan metode tinjauan pustaka sistematis dari berbagai artikel yang membahas cybercrime dan cybersecurity pada fintech yang dipublikasikan pada database online bereputasi. Hasil penelitian menunjukkan bahwa masalah cybercrime pada fintech meliputi regulasi cybercrime yang belum kuat, pencurian data dan informasi serta pencurian kekayaan intelektual sehingga memberikan dampak pada reputasi fintech. Cybersecurity untuk menanggulangi cybercrime pada fintech dapat melalui tindakan proaktif, penguatan regulasi dan pembentukan kerangka kerja atau prosedur cybersecuriy yang handal. Implikasi penelitian ini sebagai tambahan referensi bagi akademisi, praktisi, regulator dan pelaku fintech terkait perkembangan cybercrime dan cybersecurity pada fintech. Keterbatasan penelitian ini sebatas memberikan gambaran dan elaborasi dari hasil penelitian dari masing-masing artikel yang dipilih, namun tidak memberikan analisis lanjutan mengenai keterkaitan antar artikel yang dibahas. Rekomendasi penelitian selanjutnya dapat menambah ruang lingkup artikel yang diteliti atau menerapkan metode tinjauan pustaka lain atau melakukan penelitian empiris untuk mengkonfirmasi hasil penelitian ini.
\end{abstract}

Kata kunci: Cybercrime, cybersecurity, financial technology, regulasi fintech, pencurian kekayaan intelektual. 


\section{PENDAHULUAN}

Teknologi informasi yang meningkat pesat menyebabkan perubahan sosial, ekonomi dan budaya yang sangat signifikan (Fahlevi et al., 2019) serta memberikan manfaat dan dampak yang sama besar bergantung dari pengguna dari teknologi informasi tersebut (Deb, 2014; Riskiyadi, 2020). Manfaat positif yang dapat diperoleh dari teknologi informasi adalah memudahkan individu atau kelompok dalam melakukan aktifitasnya, sedangkan dampak negatif timbul karena penyalahgunaan teknologi oleh individu atau kelompok untuk tindakan kejahatan dunia maya (cybercrime) yang dapat merugikan orang lain (Gani, 2018).

Kemajuan teknologi yang semakin pesat juga diiringi dengan sistem keamanan yang semakin meningkat sebagai respon dari tindakan cybercrime yang semakin meningkat drastis (Peters et al., 2018). Akibatnya pelaku cybercrime selalu lebih aktif dan cepat membuat terobosan baru terhadap sistem keamanan yang dibentuk oleh anti cybercrime atau lebih dikenal dengan keamanan siber (cybersecurity). Kondisi yang sangat menghawatirkan terjadi apabila pelaku cybercrime adalah ahli juga dalam tindakan anti cybercrime, sehingga modus baru cybercrime sulit untuk dideteksi dan dipecahkan dengan cybersecurity. Serangan cybercrime yang terus berkembang pesat tetapi cybersecurity yang stagnan merupakan masalah yang harus segera dipecahkan (Corbet \& Gurdgiev, 2017).

Kerugian dari cybercrime sulit untuk diperkirakan dan diverifikasi sebab disamping kerugian finansial, kerugian lain akibat rusak, hilang atau bocornya data privat menyebabkan turunnya reputasi suatu perusahaan (B. Shekar \& Prabha, 2020). Akibat serangan cybercrime seluruh negara di dunia terdampak, khususnya bagi negara yang masih tahap berkembang dalam bidang teknologi informasi dan komunikasi yang ditandai dengan tingkat cybercrime yang meningkat drastis (Kshetri, 2019). Langkah antisipasi harus ditetapkan oleh pemerintah untuk menangkal cybercrime diaksud dengan menetapkan dan menerapkan regulasi tentang kejahatan cybercrime dan mendorong pihak swasta untuk ikut berkontribusi dalam memerangi cybercrime dengan memperkuat cybersecurity (Falco, 2019; Kshetri, 2019; Sunkpho et al., 2018). Terobosan lain yang dapat ditempuh untuk menekan cybercrime, dengan memberikan pendidikan etika dalam memanfaatkan teknologi informasi bagi para generasi muda (Danuri \& Suharnawi, 2017) atau dengan merancang cybersecurity yang handal (Chang, 2017; Joveda et al., 2019).

Perkembangan teknologi informasi dan komunikasi melahirkan banyak terobosan, salah satunya teknologi keuangan (fintech) (Lee \& Jae, 2018; Sangwan et al., 2019) yang berkembang untuk teknologi pembayaran, transfer dana, remitansi atau transfer dana dari luar negeri, lending atau pinjaman, crowdfunding atau urun dana, intermediasi atau perantara keuangan, investasi ritel, perencanaan keuangan, riset keuangan dan jasa keuangan lainnya (Das, 2019; Suryono et al., 2020). Hadirnya fintech dapat diterima dengan baik oleh masyarakat, sebab fintech mampu berevolusi menjadi sarana yang ampuh dalam memberikan efektifitas dan efisiensi (Kou, 2019) sesuai dengan kebiasaan dan gaya hidup masyarakat (M. C. Shekar \& Kumaran, 2019; Wang, 2021). Meskipun di sisi lain, keberadan fintech juga memberikan ancaman serius terhadap keberlangsungan lembaga keuangan, perbankan dan asuransi yang masih berkembang secara konvesional (Broby, 2021; Şcheau, 2017). Perkembangan fintech juga terus menjadi topik yang populer diberitakan media (Zavolokina et al., 2016) serta peningkatan yang drastis setiap tahunnya di sisi penelitian sejak awal kemunculannya (Kou, 2019).

Fintech yang berkembang pesat bukan tidak memiliki risiko dalam penerapannya. Risiko yang dihadapi fintech berupa risiko teknologi dan risiko bisnis yang berbeda-beda tergantung dari karateristik masing-masing fintech (Namchoochai et al., 2020; Suryono et al., 2020). Risiko finansial dan risiko teknologi dari fintech meliputi risiko diversifikasi, risiko ditransfer, risiko dikendalikan dan risiko didanai (Rahmanto \& Nasrulloh, 2019) dengan risiko teknologi merupakan tantangan terbesar dari fintech. Risiko teknologi berkenaan dengan risiko keamanan data akibat tindakan cybercrime (Singh \& Rajput, 2019). Para pelaku cybercrime dapat memanfaatkan celah fintech untuk melakukan penipuan, pemerasan, pencucian uang dan aktivitas kejahatan lainnya yang melanggar ketentuan peraturan (Nikkel, 2020), sehingga diperlukan kesadaran para pelaku fintech untuk meningkatkan cybersecurity guna melindungi data yang 
dimilikinya dari segala bentuk cybercrime serta terus berinovasi dan mengembangkan teknologi terkini (S. J. (H R. C. Kaur, 2020).

Guna meningkatkan pemahaman akademisi, praktisi, regulator dan pelaku fintech perlu dilakukan kajian literatur tentang tantangan teknologi dan antisipasi yang telah dilakukan oleh fintech selama ini. Kajian literatur yang mengulas cybercrime dan cybersecurity pada fintech diharapkan dapat memberikan gambaran tentang dinamika perkembangan cybercrime dan cybersecurity pada fintech. Penelitian ini dikembangkan dari penelitian sebelumnya yang mengulas tentang fintech (Li \& Xu, 2021; Milian et al., 2019) dan tantangan secara umum yang dihadapi fintech (Adeyoju, 2019; Suryono et al., 2020). Penelitian ini bertujuan untuk mengidentifikasi penelitian-penelitian yang telah dilakukan selama ini dan memberikan gambaran perkembangan cybercrime dan cybersecurity pada fintech, dengan harapan sebagai penambah wawasan dan pengetahuan bagi para pihak yang berkepentingan terhadap fintech dan peluang untuk penelitan di masa depan (Kitchenham \& Brereton, 2013; Xiao \& Watson, 2019).

Penelitian ini dilakukan dengan memilih, mengumpulkan, ekstraksi dan analisis artikel yang sesuai dengan pertanyan penelitian sehingga diperoleh hasil yang mencakup keseluruhan artikel yang dipilih. Hasil penelitian ini memberikan gambaran cybercrime dan cybersecurity pada fintech yang dapat menjadi acuan teori, kerangka dan model penelitian sehingga dapat bermanfaat untuk meningkatkan wawasan dan pengetahuan tentang tantangan cybercrime dan antisipasi cybersecurity pada fintech serta memberikan peluang untuk penelitian di masa depan.

\section{Tinjauan Pustaka}

\section{Cybercrime dan Cybersecurity}

Cybercrime merupakan istilah umum untuk kejahatan yang menyerang sistem komputer atau jaringan internet, dengan tujuan pencurian data, keuangan dan penyebaran kode perangkat lunak berbahaya (B. Shekar \& Prabha, 2020) yang merupakan tindakan ilegal di bidang teknologi informasi dan komunikasi sebagai bentuk modifikasi dari kejahatan konvensional (Aravazhi, 2020). Cybercrime merupakan tindakan yang dilakukan oleh pelaku untuk menghancurkan jaringan organisasi dengan mencuri data berharga, dokumen, meretas rekening bank dan mentransferkan ke rekening mereka (Irfan et al., 2018). Untuk mempelajari tindakan kejahatan tersebut diperlukan cybercriminology yang merupakan penggabungan pengetahuan dari kriminologi, psikologi, sosiologi, ilmu komputer, dan cybersecurity untuk memberikan pemahaman mendalam tentang cybercrime (Choi \& Lee, 2018). Beberapa faktor utama yang menyebabkan cybercrime berkembang dengan pesat yaitu alat, cara dan media cybercrime dengan sangat mudah diakses dan dipelajari di internet, peningkatan teknologi yang meningkat pesat terkait dengan kecepatan proses, pengolahan dan analisis data, bandwidth internet dan aktifitas jaringan internet lainnya serta terjangkaunya akses manual ke sumber informasi atau server (Singh \& Rajput, 2019).

Berbagai bentuk cybercrime yang sering digunakan oleh pelaku (Cascavilla et al., 2021; Maigida et al., 2019), diantaranya berupa spoofing email merupakan pemalsuan header email. Pesan email yang diterima tampaknya telah dikirim oleh sumber asli, aktual dan terpercaya. Modus tersebut biasanya digunakan dalam kampanye spam atau phising. Target mungkin membuka email karena berpikir bahwa email tersebut telah dikirim oleh sumber yang sah. Peretasan (hacking) merupakan pembobolan sistem komputer secara rahasia dan mencuri data berharga dari sistem tanpa izin. Penyebaran virus atau malware merupakan sekumpulan instruksi cyber yang mampu melakukan beberapa operasi jahat. Virus dan malware menghentikan fungsi normal dari program sistem dan menyisipkan beberapa kelainan dari kinerja sistem yang terserang. Virus dan malware dapat menyebar melalui email, pesan chating, penyimpanan data, multimedia, internet dan media eloktonik lainnya. Phishing merupakan tindakan mencuri informasi pribadi seperti kata sandi, detail kartu kredit, data pengguna korban yang ditarget melalui internet. Bentuk cybercrime ini dilakukan dengan spoofing email dan pesan instan kepada para korban. Peretas membuat tautan langsung yang mengarahkan korban yang ditargetkan ke halaman website palsu yang terlihat identik dengan yang website yang sebenarnya. Stalking adalah penggunaan internet untuk sarana elektronik lainnya untuk membuntuti atau memata- 
matai seseorang yang dijadikan korban. Stalking dapat berupa pelecehan, hatespeech, cyberdefamation dalam ruang lingkup cyber. Stalking umumnya melibatkan perilaku melecehkan, mengancam atau meneror yang dilakukan seseorang berulang kali, seperti membuat panggilan telepon, pengiriman pesan dan jenis intimidasi atau terror lainnya. Defamation merupakan pencemaran martabat korban di dunia maya yang merugikan reputasi seseorang atau organisasi di mata publik melalui ruang cyber. Pencemaran martabat dilakukan dengan membuat pernyataan fitnah untuk menjatuhkan reputasi individu atau perusahaan sebagai korban. Scripting website merupakan jenis kerentanan keamanan komputer atau sistem yang biasanya ditemukan dalam situs website yang memungkinkan dilakukan injeksi kode atau script oleh para pelaku cybercrime. Kerentanan script website tersebut dieksploitasi oleh pelaku untuk meminta kontrol akses ke server website (Aravazhi, 2020).

Guna melakukan tindakan antisipatif untuk menanggulangi cybercrime tersebut, diperlukan cybersecurity, yaitu tindakan pelindungan atas segala macam bentuk serangan cybercrime dan tindakan pemulihan akibat cybercrime. Beberapa hal yang harus dipenuhi dalam cybersecurity (Humayun et al., 2020; Rabii et al., 2020) adalah ketersediaan (availability), kerahasiaan (confidentiality), integritas (integrity), otentikasi (authentication) dan akuntabilitas (accountability). Ketersediaan (availability) merupakan kemampuan dan ketersediaan informasi atau data yang diperlukan untuk diakses kapanpun hanya oleh pihak yang berwenang. Kerahasiaan (confidentiality) merupakan tindakan melindungi informasi atau data dari para pihak yang tidak memiliki akses. Integritas (integrity) merupakan integritas atau keutuhan data dalam sistem untuk mencegah perubahan yang tidak sah terjadi. Otentikasi (authentication) merupakan tindakan analisis yang mengacu pada pengukuran identitas pengguna yang sebenarnya. Akuntabilitas (accountability) merupakan tanggung jawab yang tidak boleh diabaikan oleh pengguna dalam partisipasinya menggunakan sistem, yang meliputi tanggung jawab, kemauan, transparansi dan daya tanggap oleh para pengguna sistem yang digunakan (Singh \& Rajput, 2019).

\section{Cybercrime pada Fintech}

Cybercrime yang umum terjadi dalam teknologi informasi dan komunikasi juga dapat terjadi dan menyerang fintech. Cybercrime berupa cyberlaundering merupakan kejahatan yang marak terjadi saat ini, yang meliputi berbagai tahap konversi (placement), pelapisan (layering) dan pengintegrasian (integration) (Wibawa, 2017), atau hasil dari tindakan cybercrime disembunyikan dalam bentuk cyberlaundering. Salah satu bentuk cyberlaundering yang marak digunakan oleh para pelaku adalah cryptocurrency (Mabunda, 2018). Cyberlaundering secara efektif dapat ditangkal dengan legalisasi pendapatan ilegal (Karlov, 2018).

Berbagai macam serangan cybercrime yang marak dilakukan oleh pelaku adalah fintech attack. Serangan yang sering terjadi adalah memanfaatkan celah cybersecurity otentikasi multifaktor atau perlindungan koneksi aplikasi oleh para pelaku. Trojan mobile banking yang menyerang kode keamanan mobile banking hingga dapat menyebar ke domain publik. Ransomware, menyusupkan aplikasi jahat dan mengunci data pengguna dengan tujuan meminta uang tebusan. Magecarting merupakan serangan cybercrime yang menargetkan sistem transaksi pembayaran online (Nikkel, 2020). Risiko lainnya terkait dengan cybercrime semakin besar dengan semakin berkembangnya teknologi dan kecepatan jaringan yang semakin meningkat dari masa ke masa. Pengembangan fintech merupakan evolusi profesi dengan kompetensi teknis dan etika untuk mengurangi risiko yang muncul ( $\mathrm{Ng} \&$ Kwok, 2017), umumnya risiko terkait dengan tindakan cybercrime.

Berbagai penelitian menyebutkan hacking, phising dan malware berpengaruh terhadap cybersecurity compliance di sektor keuangan (Kwarto \& Angsito, 2018). Pelaku cybercrime lebih menyukai melakukan tindakan kejahatan pada e-commerce dan sistem pembayaran online karena sebagian besar informasi pribadi dan data kartu kredit disimpan dan diproses dalam aplikasi tersebut (Aravazhi, 2020). Cybercrime masih sangat sulit di antisipasi oleh pengguna $e$-commerce sehingga memberikan dampak turunnya kepercayaan pengguna pada e-commerce (Batmetan et al., 2018). Penelitian lain menyebutkan perkembangan e-commerce menjadi terhambat karena

Jurnal Manajemen dan Organisasi

Vol. 12 No. 3 Vol. 12 No. 3, Hal. 239-251 
kurang selarasnya regulasi, lemahnya perlindungan konsumen atas cybercrime (Pratamasari, 2020). Untuk itu, baik regulator maupun pelaku bisnis memandang bahwa tindakan pencegahan kritis harus dilakukan dan penerapan hukum harus terus mengikuti perkembangan kejahatan cybercrime (Fahlevi et al., 2019). Berbagai metode cybersecurity yang dapat diterapkan untuk menangkal serangan cybercrime pada fintech, diantaranya dengan metode Model to Encounter Cyber Attacks atau MECA (Cyriac \& Sadath, 2019).

Mendeteksi dan menginvestigasi tindakan cybercrime pada perusahaan fintech tidak dapat dilakukan dengan proses forensik digital tradisional. Cybercrime yang melibatkan server publik berupa cloud publik yang umum digunakan oleh perusahaan fintech diperlukan investigasi digital forensik dengan model tingkat tinggi (Baror \& Venter, 2019), berkenaan dengan pertukaran data yang selalu dinamis dalam ruang penyimpanan server publik. Tidak dimungkinkan melakukan pembekuan server publik seperti layaknya forensik digital tradisional. Penerapan cybersecurity yang handal harus dirancang dengan matang diawal perusahan fintech digagas. Selanjutnya cybersecurity yang telah terpasang wajib disandingkan dengan teknik deteksi dan investigasi yang handal pula untuk melakukan pemulihan data seandainya terjadi serangan cybercrime.

\section{METODE PENELITIAN}

Penelitian ini menggunakan metode tinjauan pustaka sistematis (systematic literatur review) dengan pertanyaan penelitian Bagaimana tantangan cybercrime yang dihadapi fintech? dan Bagaimana cybersecurity pada fintech dalam mengantisipasi ancaman cybercrime? untuk memberikan gambaran perkembangan tantangan utama yang dihadapi fintech berupa tindakan kejahatan cybercrime dan langkah antisipasi yang telah dilakukan fintech untuk menghadapi kejahatan tersebut. Sehubungan fintech merupakan inovasi baru di bidang keuangan yang banyak dibahas sejak 5 tahun terakhir, sehingga pencarian publikasi artikel pada penelitian ini kami batasi dari tahun 2016 sampai dengan 2021. Penelitian ini melakukan identifikasi, penilaian dan menginterpretasikan temuan pada suatu topik penelitian untuk menjawab pertanyaan penelitian (Jesson et al., 2011).

Proses pencarian artikel awal dilakukan dilakukan pada portal Gooogle Scholar yang selanjutnya dilakukan penelusuran pada database online bereputasi seperti ScienceDirect, Elsevier, ACM Digital Library, ABI/Inform Complete, Academic Search Complete, IEEE Xplore, SSRN, Springer, Emerald, Taylor \& Francis, World Scientific dan IGI Global dengan kata kunci "cybercrime cybersecurity fintech" namun belum ditemukan artikel yang memadai, sehingga dilakukan pengembangan pencarian pada. Selanjutnya tinjauan protokol dilakukan dengan merumuskan pertanyaan penelitian dengan mengklasifikasikan kata kunci sesuai dengan strategi populasi, intervensi, perbandingan, hasil, dan konteks dari artikel-artikel yang diperoleh. Kriteria inklusi dan eksklusi ditentukan dengan memilih artikel yang sesuai dengan pertanyaan penelitian, dengan mengesampingkan subjektifitas peneliti dalam pemilihan artikel. Selanjutnya untuk kepentingan mengorganisir artikel yang telah dipilih digunakan software Mandeley. Proses ekstraksi dan sintesis data menggunakan analisis tematik dan meta analisis (Bown \& Sutton, 2010).

Tahapan penelitian ini meliputi: perencanaan, pelaksanaan dan pelaporan, yang terbagi dalam 8 langkah yaitu merumuskan masalah, mengembangkan dan memvalidasi protokol tinjauan, mencari literatur, melakukan penyaringan literatur yang sesuai, menilai kualitas literatur, ektraksi data, analisis dan sintesis data, dan melaporkan hasil (Uman, 2011; Xiao \& Watson, 2019), sebagaimana gambar 1 berikut:

Jurnal Manajemen dan Organisasi

(JMO),

Vol. 12 No. 3, Hal. 239-251

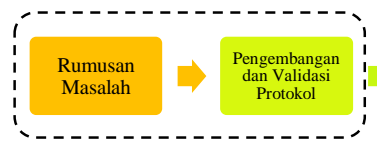

Perencanaan

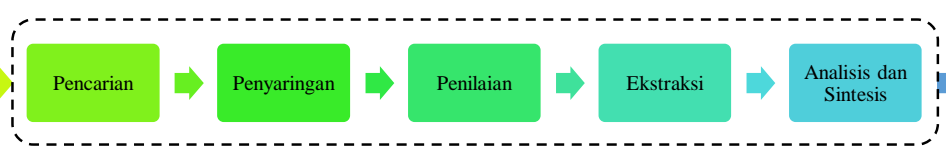

Pelaksanaan

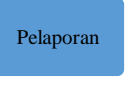

Pelaporan

Gambar 1. Metode Tinjauan Pustaka Sistematis 
Proses pencarian, penyaringan dan penilaian artikel untuk mentukan artikel-artikel yang sesuai dengan tujuan penelitian dilakukan dengan melihat topik yang dibahas pada masingmasing artikel. Berdasarkan artikel-artikel yang telah dipilih tersebut dilakukan ekstraksi dan analisis berdasarkan pertanyaan penelitian sehingga diperoleh gambaran yang komprehensif dari cybercrime pada fintech dan antisipasi cybersecurity untuk menanggulangi ancaman tersebut.

\section{HASIL DAN PEMBAHASAN}

\section{Pemilihan Artikel}

Hasil pencarian artikel dengan kata kunci "cybercrime cybersecurity fintech" pada google scholar diperoleh hasil sebanyak 1.320, selanjutnya dari hasil tersebut dilakukan pemilihan artikel yang sesuai dengan database online bereputasi yaitu ScienceDirect, Elsevier, ACM Digital Library, ABI/Inform Complete, Academic Search Complete, IEEE Xplore, SSRN, Springer, Emerald, Taylor \& Francis, World Scientific dan IGI Global. Berdasarkan hasil pemilihan artikel tersebut diperoleh hasil yang sesuai dengan topik sejumlah 35 artikel dari berbagai sumber database online, tahun terbit, metode penelitian yang digunakan serta sub topik yang membahas cybercrime dan cybersecurity pada fintech.

\section{Klasifikasi Artikel}

Terjadi peningkatan publikasi artikel setiap tahunnya yang dapat diamati dari meningkatnya jumlah publikasi artikel tentang cybercrime dan cybersecurity pada fintech sejak tahun 2017 sampai dengan 2021 sebagaimana Tabel 1. Sebaran publikasi artikel pada sumber database online bereputasi dengan topik serupa tersebar beragam dengan mayoritas artikel dipublikasikan pada SSRN sebagaimana Tabel 2.

Tabel 1. Klasifikasi Artikel Berdasarkan Tahun Terbit

\begin{tabular}{cc}
\hline Tahun & Jumlah \\
\hline 2017 & 2 \\
2018 & 3 \\
2019 & 9 \\
2020 & 9 \\
2021 & 12 \\
\hline Jumlah & 35 \\
\hline
\end{tabular}

Tabel 2. Klasifikasi Artikel Berdasarkan Sumber Online

\begin{tabular}{|c|c|}
\hline Sumber Online & Jumlah \\
\hline Elsevier & 5 \\
\hline Emerald & 3 \\
\hline IEEE Xplore & 3 \\
\hline IGI Global & 2 \\
\hline Springer & 5 \\
\hline SSRN & 14 \\
\hline Taylor \& Francis & 2 \\
\hline World Scientific & 1 \\
\hline Jumlah & 35 \\
\hline
\end{tabular}

Klasifikasi artikel berdasarkan metode penelitian dari artikel-artikel yang telah ditentukan didominasi oleh artikel dengan metode penelitian tinjauan pustaka yang diperoleh dari data sekunder berupa literatur, hasil penelitian dan laporan. Klasifikasi artikel berdasarkan metode penelitian yang digunakan sebagaimana Tabel 3 berikut:

Tabel 3. Klasifikasi Artikel Berdasarkan Jenis Penelitian

\begin{tabular}{lc}
\hline Jenis Penelitian & Jumlah \\
\hline Empiris - Data Primer & 7 \\
Empiris - Data Sekunder & 3 \\
Empiris - Eksperimen & 2 \\
Tinjauan Pustaka - Data Sekunder & 23 \\
\hline Jumlah & 35 \\
\hline
\end{tabular}


Klasifikasi artikel berdasarkan topik yang membahas ancaman cybercrime pada fintech dan antisipasi cybersecurity untuk menanggulanginya sebagaimana Tabel 4 berikut:

Tabel 4. Klasifikasi Artikel Berdasarkan Jenis Penelitian

\begin{tabular}{|c|c|c|}
\hline Topik & Jumlah & Penulis \\
\hline $\begin{array}{l}\text { Ancaman cybercrime dan antisipasi } \\
\text { cybersecurity pada fintech }\end{array}$ & 14 & $\begin{array}{l}\text { (Adeyoju, 2019; Boitan \& Marchewka- } \\
\text { Bartkowiak, 2021; Corbet \& Gurdgiev, 2017; } \\
\text { Cyriac \& Sadath, 2019; Faya \& Ogbuefi, 2019; } \\
\text { Huang \& Madnick, 2020; G. Kaur et al., 2021; } \\
\text { Malladi et al., 2021; Mehrotra \& Menon, 2021; } \\
\text { Milian et al., 2019; Namchoochai et al., 2020; Ng } \\
\text { \& Kwok, 2017; Palmié et al., 2019; Sharma, 2019) }\end{array}$ \\
\hline $\begin{array}{l}\text { Persepsi atas cybersecurity fintech } \\
\text { dalam menanggulagi cybercrime }\end{array}$ & 2 & $\begin{array}{l}\text { (Asante-Offei \& Yaokumah, 2021; Ogbanufe \& } \\
\text { Kim, 2018) }\end{array}$ \\
\hline $\begin{array}{l}\text { Dampak, penyebab, modus dan } \\
\text { investigasi forensik cybercrime pada } \\
\text { fintech }\end{array}$ & 3 & $\begin{array}{l}\text { (Al-Harrasi et al., 2021; Nikkel, 2020; Vedral, } \\
\text { 2021) }\end{array}$ \\
\hline $\begin{array}{l}\text { Regulasi pengaturan fintech untuk } \\
\text { antisipasi } \\
\text { cybersecurity }\end{array}$ & 6 & $\begin{array}{l}\text { (Amstad, 2019; Bagby \& Packin, 2020; Bagby \& } \\
\text { Reitter, 2019; Laidlaw, 2021; Ojo \& Nwaokike, } \\
\text { 2019; Teigland } \text { et al., 2018) }\end{array}$ \\
\hline $\begin{array}{l}\text { Kerangka kerja } \\
\begin{array}{l}\text { cybersecurity } \\
\text { cybercrime }\end{array}\end{array}$ & 10 & $\begin{array}{l}\text { (Bouveret, 2019; Chari, 2020; Creado \& Ramteke, } \\
\text { 2020; Lubin, 2021; Najaf } \text { et al., 2021; Noor et al., } \\
\text { 2019; Santucci, 2018; Singh \& Rajput, 2019; } \\
\text { Uddin } \text { et al., 2020; Yusif \& Hafeez-Baig, 2021) }\end{array}$ \\
\hline
\end{tabular}

Permasalahan utama yang dirasakan fintech adalah berbagai macam bentuk cybercrime yang dapat menghambat operasi bisnisnya, sehingga diperlukan perjuangan ekstra dalam menerapkan cybersecurity untuk melawan ancaman cybercrime tersebut.

\section{Masalah Cybercrime pada Fintech}

Masalah utama yang dihadapi fintech adalah cybercrime yang selalu muncul modus baru seiring dengan perkembangan teknologi informasi dan komunikasi (Al-Harrasi et al., 2021; Vedral, 2021). Masalah cybercrime menyebabkan berbagai kendala meliputi regulasi penanggulangan cybercrime pada fintech masih belum kuat, hilang, berubah atau bocornya data dan informasi, serta pencurian kekayaan intelektual (Faya \& Ogbuefi, 2019) yang menyebabkan merosotnya kepercayaan publik (Adeyoju, 2019; Boitan \& Marchewka-Bartkowiak, 2021; Corbet \& Gurdgiev, 2017; Cyriac \& Sadath, 2019; Faya \& Ogbuefi, 2019; Huang \& Madnick, 2020; G. Kaur et al., 2021; Malladi et al., 2021; Mehrotra \& Menon, 2021; Milian et al., 2019; Namchoochai et al., 2020; Ng \& Kwok, 2017; Palmié et al., 2019; Sharma, 2019).

Uraian kendala tersebut sebagai berikut:

1. Regulasi

Fintech mengalami kendala regulasi dan penerapannya, sebab regulasi sering lambat merepon perkembangan teknologi informasi dan komunikasi yang berkembang drastis. Di sisi yang lain regulasi perlindungan data dan informasi fintech merupakan tantangan global yang melibatkan negara-negara lain di dunia dan sebagian negara masih belum mendukung fintech di negaranya, sebab sebagian negara beranggapan fintech berpotensi merusak stabilitas keuangan konvesioal. Dampak global yang ditimbulkan fintech membutuhkan regulasi yang berlaku internasional (Laidlaw, 2021) dan hal tersebut membutuhkan proses yang cukup lama. Dalam berbagai kondisi regulasi cybercrime pada fintech masih menerapkan regulasi cybercrime yang bersifat umum yang menyebabkan pelaksanaan regulasi tersebut tidak maksimal diterapkan pada fintech. Sifat fintech yang dinamis menuntut regulasi yang dinamis pula agar mampu mengatur fintech yang berkembang sangat drastis (Bagby \& Packin, 2020; Bagby \& Reitter, 2019; Faya \& Ogbuefi, 2019; Ojo \& Nwaokike, 2019; Teigland et al., 2018).

\section{Data dan Informasi}

Potensi serangan cybercrime pada fintech menyebabkan risiko hilang, berubah atau bocornya suatu data atau informasi yang dimiliki fintech, sebab ancaman cybercrime selalu lebih 
unggul dibandingkan dengan cybersecurity yang dimiliki fintech, sehingga diperlukan pembaharuan cybersecurity untuk menanggulangi segala bentuk ancaman cybercrime yang mengalami perkembangan pesat dari waktu ke waktu (Akhta et al., 2021).

3. Pencurian Kekayaan Intelektual

Berkembangnya teknologi inovatif maka muncul peningkatan pencurian hak kekayaan intelektual berupa pencurian hak paten, hak cipta dan rahasia dagang yang diawali dengan serangan cybercrime pada fintech yang menjadi korban (Al-Harrasi et al., 2021).

4. Kepercayaan Publik

Dampak dari permasalahan sebagaimana disampaikan di atas menyebabkan tergerusnya kepercayaan publik terhadap fintech. Kepercayaan publik sulit dikembalikan apabila pernah terjadi kebocoran data atau informasi akibat serangan cybercrime pada fintech (Asante-Offei \& Yaokumah, 2021; Ogbanufe \& Kim, 2018).

\section{Antisipasi Cybersecurity pada Fintech}

Perkembangan fintech yang sangat pesat rentan terhadap serangan cybercrime, sehingga fintech harus merencanakan dan membangun cybersecurity yang handal dan efektif untuk melindungi data dan keuangan dari serangan cybercrime yang sewaktu-waktu dapat melanda fintech. Langkah terbaik untuk melindungi data dan informasi fintech dengan menerapkan cybersecurity yang handal sejak awal bisnis fintech digagas dan cybersecurity harus menjadi prioritas utama. Langkah yang dapat ditempuh untuk melindungi fintech dari serangan cybercrime meliputi:

\section{Tindakan Proaktif}

Tindakan proaktif cyersecurity dalam menanggulangi cybercrime yang perlu tempuh oleh fintech dan pemerintah sebagai pemangku kebijakan dalam penerapan regulasi (Chang et al., 2018; Faya \& Ogbuefi, 2019) adalah:

a. Mengembangkan kerangka kerja cyersecurity secara komprehensif yang mencakup pencegahan, pendeteksian, pemantauan, pembagian informasi, literasi keuangan dan teknologi serta rencana pemulihan atau recovery.

b. Perlindungan arsitektur akses data dan informasi secara komprehensif untuk menanggulangi risiko cybercrime dari penggunaan data global.

c. Pengawasan regulasi untuk memastikan fintech menerapkan cybersecurity yang handal dan tangguh.

d. Peningkatan kesadaran dan pemahaman pentinya cybersecurity dengan edukasi dan pelatihan bagi para pengguna layanan fintech.

\section{Regulasi Fintech}

Perusahaan fintech membutuhkan peraturan perundang-undangan yang dinamis yang dapat mengatasi risiko saat kondisi fintech yang berubah dengan cepat. Peraturan perundang-undangan tidak boleh menghambat inovasi dan kreasi dari pengembangan fintech secara komprehensif dan sistematis (Fahlevi et al., 2019). Regulasi juga memberikan kepastian hukum atas segala tindakan cybercrime yang membahayakan fintech sehingga para pelaku usaha, pelanggan dan regulator pegawas memiliki sandaran yang jelas tentang bagaimana harus berbuat dan bertindak sesuai dengan peraturan yang berlaku. Regulasi harus mendukung penuh pengembangan fintech dengan tetap berpegang teguh pada prinsip-prinsip menjaga harkat dan martabat bangsa (Amstad, 2019; Bagby \& Packin, 2020; Bagby \& Reitter, 2019; Laidlaw, 2021; Ojo \& Nwaokike, 2019; Teigland et al., 2018).

3. Langkah Teknis dalam Menerapkan Cybersecurity pada Fintech

Langkah teknis yang dapat dilakukan untuk menanggulangi cybercrime pada fintech dengan membuat kerangka kerja dan prosedur cybersecurity yang handal (Creado \& Ramteke, 2020; Najaf et al., 2021; Singh \& Rajput, 2019; Uddin et al., 2020) dengan memetakan risiko yang rentan cybercrime (Bouveret, 2019; Chari, 2020; Lubin, 2021; Santucci, 2018) dan menetapkan sensitifitas yang tinggi untuk mendeteksi cybercrime (Noor et al., 2019) serta meningkatkan sumber daya, melakukan pengawasan yang intensif (Yusif \& Hafeez-Baig, 2021) dan melakukan investigasi forensik apabila tekah terjadi cybercrime (Nikkel, 2020). 
Risiko cybercrime yang memanfaatkan celah keamanan cybersecurity pada fintech menjadi pintu masuk terjadinya cybercrime sehingga dibutuhkan langkah cybersecurity yang tepat (Aravazhi, 2020) dengan berbagai tindakan berikut:

a. Melindungi dan memantau titik akses nirkabel, titik akses jaringan, dan perangkat yang terhubung ke jaringan dengan sistem keamanan berlapis dan mengontrol seluruh akses pengguna ke sumber informasi.

b. Mengontrol dan membatasi hak akses pengguna internal ke file atau data hanya yang berhubungan tugas pekerjaan.

c. Mencegah dan mengamankan semua pengguna dan pengelola sistem yang menjadi target cybercrime.

d. Otentifikasi pada program pemindaian virus, trojan, malware dan program jahat lainnya.

e. Melakukan pemindaian secara berkala menggunakan program antispyware untuk mendeteksi spyware, adware dan bot (robot perangkat lunak) dan program berbahaya lainnya.

f. Penyediaan edukasi dan pelatihan tentang kesadaran pentingnya keamanan dan kehati-hatian dalam menggunakan layanan internet.

\section{KESIMPULAN}

Cybercrime merupakan keniscayaan yang selamanya terus ada seiring dengan perkembangan teknologi informasi dan komunikasi yang berkembang pesat, sehingga diperlukan cybersecurity yang handal dan efektif untuk menanggulanginya. Tantangan cybercrime pada fintech meliputi regulasi cybercrime yang belum kuat, pencurian data dan informasi serta pencurian kekayaan intelektual sehingga berdampak pada reputasi fintech. Guna melakukan mitigasi terhadap tantangan cybercrime tersebut diperlukan cybersecurity melalui tindakan proaktif, penguatan regulasi dan pembentukan kerangka kerja atau prosedur cybersecuriy yang handal, efektif dan efisien.

\section{Acknowledgement:}

We gratefully acknowledge funding provided by the Lembaga Penelitian Pengabdian kepada Masyarakat (LPPM) Universitas Trunojoyo Madura.

\section{DAFTAR PUSTAKA}

Adeyoju, A. (2019). Cybercrime and Cybersecurity: FinTech's Greatest Challenges. SSRN Electronic Journal, 1-5. https://doi.org/10.2139/ssrn.3486277.

Akhta, S., Sheorey, P. A., Bhattacharya, S., \& Ajith, K. V. V. (2021). Cyber Security Solutions for Businesses in Financial Services: Challenges, Opportunities, and the Way Forward. International Journal of Business Intelligence Research, 12(1), 82-97. https://doi.org/10.4018/IJBIR.20210101.oa5.

Al-Harrasi, A., Shaikh, A. K., \& Al-Badi, A. (2021). Towards Protecting Organisations' Data by Preventing Data Theft by Malicious Insiders. International Journal of Organizational Analysis, 20-21. https://doi.org/10.1108/IJOA-01-2021-2598.

Amstad, M. (2019). Regulating Fintech: Objectives, Principles, and Practices. Asian Development Bank Institute Working Paper Series 1016, 1-13. https://doi.org/10.2139/ssrn.3541003.

Aravazhi, M. S. (2020). Understanding Cyber Crime and Cyber Laundering: Threat and Solution. EPRA International Journal of Research and Development (IJRD), 5(1), 34-38. https://doi.org/10.36713/epra2016. e-Offei, K. O., \& Yaokumah, W. (2021). Cyber-Identity Theft and Fintech Services: Technology Threat Avoidance Perspective. Journal of Information Technology Research, 14(3), 1-19. https://doi.org/10.4018/jitr.2021070101.

Bagby, J. W., \& Packin, N. G. (2020). RegTech and Predictive Lawmaking: Closing the RegLag between Prospective Regulated Activity and Regulation. Michigan Business \& Entrepreneurial Law Review, 10(2), 127-177. 
https://doi.org/10.36639/mbelr.10.2.regtech.

Bagby, J. W., \& Reitter, D. (2019). Anticipatory FinTech Regulation: On Deploying Big Data Analytics to Predict the Direction, Impact and Control of Financial Technology. SSRN Electronic Journal, 1-59. https://doi.org/10.2139/ssrn.3456844.

Baror, S. O., \& Venter, H. S. (2019). A Taxonomy for Cybercrime Attack in the Public Cloud. 14th International Conference on Cyber Warfare and Security, ICCWS 2019, 505-515.

Batmetan, J. R., Watung, H., Nayoan, L., \& Untu, A. E. (2018). Pengaruh Perilaku Cyber Crime Terhadap Pengguna Aplikasi E-commerce. OSF Preprints, 1-5. https://doi.org/10.31219/osf.io/gukcf.

Boitan, I. A., \& Marchewka-Bartkowiak, K. (2021). Fostering Innovation and Competitiveness with Fintech, RegTech, and SupTech. IGI Global. USA: Hershey PA.

Bouveret, A. (2019). Cyber Risk for the Financial Services Sector. Journal of Financial Transformation, 49, 78-85.

Bown, M. J., \& Sutton, A. J. (2010). Quality Control in Systematic Reviews and Meta-analyses. European Journal of Vascular \& Endovascular Surgery, 40(5), 669-677. https://doi.org/10.1016/j.ejvs.2010.07.011.

Broby, D. (2021). Financial Technology and the Future of Banking. Financial Innovation, 7(47), 1-19. https://doi.org/10.1186/s40854-021-00264-y.

Cascavilla, G., Tamburri, D. A., \& Van Den Heuvel, W. J. (2021). Cybercrime Threat Intelligence: A Systematic Multi-vocal Literature Review. Computers and Security, 105, 102258. https://doi.org/10.1016/j.cose.2021.102258.

Chang, L. Y. C. (2017). Cybercrime and Cyber Security in ASEAN. Comparative Criminology in Asia, 135-148. https://doi.org/10.1007/978-3-319-54942-2.

Chang, L. Y. C., Zhong, L. Y., \& Grabosky, P. N. (2018). Citizen Co-Production of Cyber Security: Self-Help, Vigilantes, and Cybercrime. Regulation and Governance, 12(1), 101114. https://doi.org/10.1111/rego.12125.

Chari, K. (2020). Fraud Risk in Digitized Fintech Ecosystem: Troubling Trends, Issues and Approaches to Mitigate Risk. SSRN Electronic Journal, 1-8. https://doi.org/10.2139/ssrn.3680456.

Choi, K., \& Lee, C. S. (2018). The Present and Future of Cybercrime, Cyberterrorism, and Cybersecurity. International Journal of Cybersecurity Intelligence and Cybercrime, 1(1), 1-4. https://doi.org/10.52306/01010218YXGW4012.

Corbet, S., \& Gurdgiev, C. (2017). Financial Digital Disruptors and Cyber-Security Risks: Paired and Systemic. Forthcoming in Journal of Terrorism \& Cyber Insurance, 1(2), 1-20. https://doi.org/10.2139/ssrn.2892842.

Creado, Y., \& Ramteke, V. (2020). Active Cyber Defence Strategies and Techniques for Banks and Financial Institutions. Journal of Financial Crime, 27(3), 771-780. https://doi.org/10.1108/JFC-01-2020-0008.

Cyriac, N. T., \& Sadath, L. (2019). Is Cyber Security Enough-A Study on Big Data Security Breaches in Financial Institutions. 2019 4th International Conference on Information Systems and Computer Networks, ISCON 2019, 380-385. https://doi.org/10.1109/ISCON47742.2019.9036294.

Danuri, M., \& Suharnawi. (2017). Trend Cyber Crime dan Teknologi Informasi di Indonesia. Informasi Komputer Akuntansi Dan Manajemen, 13(2), 55-65. https://doi.org/10.53845/infokam.v13i2.133.

Das, S. R. (2019). The Future of Fintech. Financial Management, 48(4), 981-1007. https://doi.org/10.1111/fima.12297.

Deb, S. (2014). Information Technology, Its Impact on Society and Its Future. Advances in Computing, 4(1), 25-29. https://doi.org/10.5923/j.ac.20140401.07.

Fahlevi, M., Saparudin, M., Maemunah, S., Irma, D., \& Ekhsan, M. (2019). Cybercrime Business Digital in Indonesia. E3S Web of Conferences, 125(20101), 1-5. https://doi.org/10.1051/e3sconf/201912521001.

Falco, G. (2019). Cybersecurity Principles for Space Systems. Journal of Aerospace Information 
Systems, 16(2), 61-70. https://doi.org/10.2514/1.I010693.

Faya, M., \& Ogbuefi, N. (2019). Cybersecurity in the Age of FinTech and Digital Business. Cyber Secure Nigeria 2019 Conference, 6-10. https://ssrn.com/abstract=3606866.

Gani, A. G. (2018). Cybercrime (Kejahatan Berbasis Komputer). Jurnal Sistem Informasi, 5(1), 16-29. https://doi.org/https://doi.org/10.35968/jsi.v5i1.18.

Huang, K., \& Madnick, S. (2020). Cyber Securing Cross-border Financial Services: Calling for a Financial Cybersecurity Action Task Force. Working Paper CISL\# 2020-08, 1-10. https://doi.org/10.2139/ssrn.3570140.

Humayun, M., Niazi, M., Jhanjhi, N., Alshayeb, M., \& Mahmood, S. (2020). Cyber Security Threats and Vulnerabilities: A Systematic Mapping Study. Arabian Journal for Science and Engineering, 45(4), 3171-3189. https://doi.org/10.1007/s13369-019-04319-2.

Irfan, M., Ramdhani, M. A., Darmalaksana, W., Wahana, A., \& Utomo, R. G. (2018). Analyzes of Cybercrime Expansion in Indonesia and Preventive Actions. IOP Conference Series: Materials Science and Engineering, 434(012257), 1-6. https://doi.org/10.1088/1757899X/434/1/012257.

Jesson, J. K., Matheson, L., \& Lacey, F. M. (2011). Doing Your Literature Review: Traditional and Systematic Techniques. SAGE Publications. California: Thousand Oaks.

Joveda, N., Khan, M. T., \& Pathak, A. (2019). Cyber Laundering: A Threat to Banking Industries in Bangladesh: In Quest of Effective Legal Framework and Cyber Security of Financial Information. International Journal of Economics and Finance, 11(10), 54. https://doi.org/10.5539/ijef.v11n10p54.

Karlov, R. G. (2018). The Impact of New Methods of Money Laundering on the Economy of the State. KnE Social Sciences, 3(2), 491. https://doi.org/10.18502/kss.v3i2.1581.

Kaur, G., Lashkari, Z. H., \& Lashkari, A. H. (2021). Understanding Cybersecurity Management in FinTech: Challenges, Strategies, and Trends. In Springer. Switzerland AG. http://www.springer.com/series/16360.

Kaur, S. J. (H R. C. (2020). Reviewing Existential Threats Involved in Fintech. UGC Care Journal, 40(36), 58-62.

Kitchenham, B., \& Brereton, P. (2013). A Systematic Review of Systematic Review Process Research in Software Engineering. Information and Software Technology, 55(12), 20492075. https://doi.org/10.1016/j.infsof.2013.07.010.

Kou, G. (2019). Introduction to the special issue on FinTech. Financial Innovation, 5(1), 4-6. https://doi.org/10.1186/s40854-019-0161-1.

Kshetri, N. (2019). Cybercrime and Cybersecurity in Africa. Journal of Global Information Technology Management, 22(2), 77-81. https://doi.org/10.1080/1097198X.2019.1603527.

Kwarto, F., \& Angsito, M. (2018). Pengaruh Cyber Crime Terhadap Cyber Security Compliance di Sektor Keuangan. In Jurnal Akuntansi Bisnis (Vol. 11, Issue 2, pp. 99-110). https://doi.org/10.30813/jab.v11i2.1382.

Laidlaw, E. (2021). Privacy and Cybersecurity in Digital Trade: The Challenge of Cross Border Data Flows. SSRN Electronic Journal, 1-81. https://doi.org/10.2139/ssrn.3790936.

Lee, I., \& Jae, Y. (2018). Fintech: Ecosystem, Business Models, Investment Decisions, and Challenges. Business Horizons, 61(1), 35-46. https://doi.org/10.1016/j.bushor.2017.09.003.

Li, B., \& Xu, Z. (2021). Insights into Financial Technology (FinTech): A Bibliometric and Visual Study. Financial Innovation, 7(69), 1-28. https://doi.org/10.1186/s40854-021-00285-7.

Lubin, A. (2021). Insuring Evolving Technology. Connecticut Insurance Law Journal . Indiana Legal Studies Research Paper No. 441, 28(1), 1-31.

Mabunda, S. (2018). Cryptocurrency: The New Face of Cyber Money Laundering. 2018 International Conference on Advances in Big Data, Computing and Data Communication Systems, IcABCD 2018, 1-6. https://doi.org/10.1109/ICABCD.2018.8465467.

Maigida, A. M., Abdulhamid, S. M., Olalere, M., Alhassan, J. K., Chiroma, H., \& Dada, E. G. (2019). Systematic Literature Review and Metadata Analysis of Ransomware Attacks and Detection Mechanisms. Journal of Reliable Intelligent Environments, 5(2), 67-89. 
https://doi.org/10.1007/s40860-019-00080-3.

Malladi, C. M., Soni, R. K., \& Srinivasan, S. (2021). Digital Financial Inclusion: Next FrontiersChallenges and Opportunities. CSI Transactions on ICT, 9(2), 127-134. https://doi.org/10.1007/s40012-021-00328-5.

Mehrotra, A., \& Menon, S. (2021). Second Round of FinTech - Trends and Challenges. 2nd International Conference on Computation, Automation and Knowledge Management, ICCAKM 2021, 243-248. https://doi.org/10.1109/ICCAKM50778.2021.9357759.

Milian, E. Z., Spinola, M. de M., \& Carvalho, M. M. d. (2019). Fintechs: A Literature Review and Research Agenda. Electronic Commerce Research and Applications, 34(100833), 121. https://doi.org/10.1016/j.elerap.2019.100833.

Najaf, K., Mostafiz, M. I., \& Najaf, R. (2021). Fintech Firms and Banks Sustainability: Why Cybersecurity Risk Matters? International Journal of Financial Engineering, 08(02), 2150019. https://doi.org/10.1142/S2424786321500195.

Namchoochai, R., Kiattisin, S., Darakorn Na Ayuthaya, S., \& Arunthari, S. (2020). Elimination of FinTech Risks to Achieve Sustainable Quality Improvement. Wireless Personal Communications, 115, 3199-3214. https://doi.org/10.1007/s11277-020-07201-9.

Ng, A. W., \& Kwok, B. K. B. (2017). Emergence of Fintech and Cybersecurity in a Global Financial Centre: Strategic Approach by a Regulator. Journal of Financial Regulation and Compliance, 25(4), 1-14. https://doi.org/10.1108/jfrc.2008.31116baa.001.

Nikkel, B. (2020). Fintech Forensics: Criminal Investigation and Digital Evidence in Financial Technologies. Forensic Science International: Digital Investigation, 33, 200908. https://doi.org/10.1016/j.fsidi.2020.200908.

Noor, U., Anwar, Z., Amjad, T., \& Choo, K. K. R. (2019). A Machine Learning-based FinTech Cyber Threat Attribution Framework Using High-level Indicators of Compromise. Future Generation Computer Systems, 96, 227-242. https://doi.org/10.1016/j.future.2019.02.013.

Ogbanufe, O., \& Kim, D. J. (2018). Comparing Fingerprint-based Biometrics Authentication Versus Traditional Authentication Methods for e-Payment. Decision Support Systems, 106, 1-14. https://doi.org/10.1016/j.dss.2017.11.003.

Ojo, O., \& Nwaokike, U. (2019). Disruptive Technology and the Fintech Industry in Nigeria: Imperatives for Legal and Policy Responses. Gravitas Review of Business and Property Law, 9(3), 1-19. https://doi.org/10.2139/ssrn.3306164.

Palmié, M., Wincent, J., Parida, V., \& Caglar, U. (2019). The Evolution of the Financial Technology Ecosystem: An Introduction and Agenda for Future Research on Disruptive Innovations in Ecosystems. Technological Forecasting \& Social Change, 151, 119779. https://doi.org/10.1016/j.techfore.2019.119779.

Peters, G., Shevchenko, P. V., \& Cohen, R. (2018). Understanding Cyber-Risk and CyberInsurance. Macquarie University Faculty of Business \& Economics Research Paper, 1-30. https://doi.org/10.2139/ssrn.3200166.

Pratamasari, A. (2020). Cybersecurity and Custom Regulations as Trade Barriers in ASEAN eCommerce: Case of Indonesian e-Commerce. Global Strategis, 14(1), 1-16. https://doi.org/10.20473/jgs.14.1.2020.1-16.

Rabii, A., Assoul, S., Ouazzani Touhami, K., \& Roudies, O. (2020). Information and Cyber Security Maturity Models: A Systematic Literature Review. Information and Computer Security, 28(4), 627-644. https://doi.org/10.1108/ICS-03-2019-0039.

Rahmanto, D. N. A., \& Nasrulloh. (2019). Risiko dan Peraturan: Fintech untuk Sistem Stabilitas Keuangan. Inovasi, 15(1), 44-52. https://doi.org/10.29264/jinv.v15i1.4339.

Riskiyadi, M. (2020). Investigasi Forensik terhadap Bukti Digital dalam Mengungkap Cybercrime. CyberSecurity Dan Forensik Digital, 3(2), 12-21. https://doi.org/10.14421/csecurity.2020.3.2.2144.

Sangwan, V., Harshita, Prakash, P., \& Singh, S. (2019). Financial Technology: A Review of Jurnal Manajemen Extant Literature. Studies in Economics and Finance, 37(1), 71-88. dan Organisasi https://doi.org/10.1108/SEF-07-2019-0270.

Santucci, L. (2018). Quantifying Cyber Risk in the Financial Services Industry. FRB of Hal.239-251 
Philadelphia Payment Cards Center Discussion Paper No. 18-3, 1-30.

Şcheau, M. C. (2017). Methods of Laundering Money Resulted from Cyber-Crime. Economic Computation and Economic Cybernetics Studies and Research, 51(3), 299-315.

Sharma, N. (2019). Banking and FinTech (Financial Technology) Embraced with IoT Device. Advances in Intelligent Systems and Computing, 1042, 197-211. https://doi.org/10.1007/978-981-32-9949-8_15.

Shekar, B., \& Prabha, A. (2020). Impacts of Cyber Crime on the Victims. UGC Care Journal, 40(50), 2731-2737. https://digital.wings.uk.barclays/for-everyone/milestone/impacts-ofcyber-crime/.

Shekar, M. C., \& Kumaran, R. (2019). Fintech - An Exploratory Study and Its Applications. The Management Accountant, 51-54.

Singh, P., \& Rajput, R. S. (2019). Cybersecurity Analysis in the Context of Digital Wallets. International Journal of Advanced Studies of Scientific Research, 4(3), 522-525.

Sunkpho, J., Ramjan, S., \& Ottamakorn, C. (2018). Cybersecurity Policy in ASEAN Countries. Information Institute Conferences, 1-8.

Suryono, R. R., Budi, I., \& Purwandari, B. (2020). Challenges and Trends of Financial Technology (Fintech): A Systematic Literature Review. Information, 11(12), 1-20. https://doi.org/10.3390/info11120590.

Teigland, R., Siri, S., Larsson, A., \& Puertas, A. M. (2018). The Rise and Development of FinTech: Accounts of Disruption from Sweden and Beyond. Routledge. New York: Third Avenue.

Uddin, M. H., Ali, M. H., \& Hassan, M. K. (2020). Cybersecurity hazards and Financial System Vulnerability: A Synthesis of Literature. In Risk Management (Vol. 22, Issue 4). Palgrave Macmillan UK. https://doi.org/10.1057/s41283-020-00063-2.

Uman, L. S. (2011). Systematic Reviews and Meta-Analyses. Journal of the Canadian Academy of Child and Adolescent Psychiatry, 20(1), 57-59. https://www.ncbi.nlm.nih.gov/pmc/articles/PMC3024725/.

Vedral, B. (2021). The Vulnerability of the Financial System to a Systemic Cyberattack. 13th International Conference on Cyber Conflict (CyCon), 95-110. https://doi.org/10.23919/CyCon51939.2021.9468291.

Wang, J. S. (2021). Exploring Biometric Identification in FinTech Applications Based on the Modified TAM. Financial Innovation, 7(42), 1-24. https://doi.org/10.1186/s40854-02100260-2.

Wibawa, I. (2017). Cyber Money Laundering (Salah Satu Bentuk White Collar Crime abad 21). Jurnal Pemikiran Hukum Dan Hukum Islam, 8(2), 240-254. https://doi.org/10.21043/yudisia.v8i2.3238.

Xiao, Y., \& Watson, M. (2019). Guidance on Conducting a Systematic Literature Review. Journal of Planning Education and Research, 39(1), 1-20. https://doi.org/10.1177/0739456X17723971.

Yusif, S., \& Hafeez-Baig, A. (2021). A Conceptual Model for Cybersecurity Governance. Journal of Applied Security Research, 16(4), 490-513. https://doi.org/10.1080/19361610.2021.1918995.

Zavolokina, L., Dolata, M., \& Schwabe, G. (2016). The FinTech Phenomenon: Antecedents of Financial Innovation Perceived by the Popular Press. Financial Innovation, 2(16), 1-16. https://doi.org/10.1186/s40854-016-0036-7. 